\title{
The occurrence of specific markers of Bacteroides fragilis group, $B$. dorei and antibiotic-resistance genes in the wastewater treatment plants
}

\author{
Sebastian Niestępski ${ }^{1,{ }^{*}}$, Monika Harnisz ${ }^{1}$, Ewa Korzeniewska ${ }^{1}$, and Adriana Osińska ${ }^{1}$ \\ ${ }^{1}$ Department of Environmental Microbiology, University of Warmia and Mazury in Olsztyn, \\ Prawocheńskiego 1, 10-957 Olsztyn, Poland.
}

\begin{abstract}
Wastewater treatment plants (WWTPs) are one of the main transmission sources of pathogenic bacteria and antibiotic-resistance genes in the natural environment. In this study, the presence of specific markers of Bacteroides fragilis group (BFG), B. dorei and genes encoding resistance to beta-lactams $(\operatorname{cep} \mathrm{A}, c f x \mathrm{~A})$, tetracyclines $(\operatorname{tet}(\mathrm{Q}))$, macrolides, lincosamides and streptogramins (MLS) mechanism $(\operatorname{erm} \mathrm{F}, \operatorname{lin} \mathrm{A})$ was analyzed by standard PCR in the inflows and outflows from three wastewater treatment plants with the activated sludge process. Genetic material was isolated from wastewater samples with the use of two commercial kits for genomic DNA extraction, the Fast DNA SPIN Kit for Soil and the Genomic Micro AX Bacteria Gravity Kit. The quality of the isolated genetic material differed between the tested isolation kits. The Fast DNA SPIN Kit for Soil was more effective in detecting $c f x \mathrm{~A}$, erm $\mathrm{F}$ and $\operatorname{lin} \mathrm{A}$ genes. However, both extraction kits effectively identified tet(Q), bfr and HF183/BacR287 genes in all wastewater samples. The results of the study indicate that genes specific to $\mathrm{BFG}$ and $B$. dorei, and genes encoding resistance to MLS and tetracyclines are not completely eliminated during the wastewater treatment process.
\end{abstract}

\section{Introduction}

The anaerobic bacteria of the genus Bacteroides naturally colonize the human and animal digestive tracts [1]. The genus Bacteroides comprises 38 potentially pathogenic species of bacteria, including $B$. dorei, a member of the Bacteroides fragilis group (BFG) [2]. This bacterial group is characterized by high levels of drug resistance. Bacteroides spp., including BFG, are excreted in feces and evacuated via sewers to wastewater treatment plants (WWTPs). These microorganisms contain catalase, an enzyme which enables bacteria to survive wastewater treatment processes, including aeration. The surviving bacteria are evacuated from the plant with treated wastewater. The presence of BFG in the natural environment testifies to fecal contamination. Molecular methods which detect specific

\footnotetext{
* Corresponding author: sebastian.niestepski@uwm.edu.pl
} 
markers of BFG, such as bfr and HF183/BacR287 genes, support relatively quick and reliable identification of fecal contamination in the natural environment [3, 4].

The overuse and misuse of antibiotics in home and hospital therapy, veterinary practice and agriculture contributes to the release of bacteria into the natural environment and the dissemination of drug-resistant strains [5, 6]. Antibiotic-resistant bacteria (ARB) and antibiotic-resistance genes (ARGs) are present in various environments, including hospital wastewater, WWTPs, rivers and lakes [7-10]. Infections caused by drug-resistant bacteria are increasingly difficult to treat, which poses a serious threat to public health [11].

Wastewater treatment plants are one of the main anthropogenic sources responsible for the dissemination of antibiotics, ARB and ARGs in the natural environment $[5,8,12]$. Wastewater treatment processes, in particular those that rely on activated sludge, create a supportive environment for the development of antibiotic resistance in bacteria [12, 13]. Subinhibitory concentrations of antibiotics in wastewater promote the selection of bacteria resistant to these antimicrobials [13-15]. Antibiotic-resistance genes are exchanged between bacteria, which leads to horizontal gene transfer (HGT) [16]. Every WWTP harbors bacteria resistant to specific antibiotics, but significant differences in the prevalence of drug resistance markers are rarely observed between untreated and treated wastewater [17].

The progress in molecular biology has led to the development of various methods for the isolation and purification of DNA from different samples. There is a broad selection of commercial DNA extraction kits on the market. However, the quality of genetic material extracted from the same sample can differ considerably when DNA isolation kits that rely on different extraction techniques are used [18-21]. This is a very important consideration because the quality of extracted DNA directly influences the results of genetic analyses.

The aim of this study was to determine the occurrence of specific markers of BFG, B. dorei and genes encoding resistance to beta-lactams, macrolides, lincosamides, streptogramins (MLS) mechanism and tetracyclines in untreated and treated wastewater from three WWTPs with the activated sludge process. The quality of genetic material isolated from wastewater with the use of two commercial DNA extraction kits was compared.

\section{Materials and methods}

\subsection{Sampling sites and samples collection}

The sewage samples of untreated and treated wastewater (UWW and TWW, respectively) were collected at municipal wastewater treatment plants in Biskupiec, Mikołajki and Lidzbark, Poland in July 2016. All wastewater treatment plants use different biological activated sludge system. Technical description of the studied WWTPs are reported in Table 1. Untreated wastewater in Biskupiec WWTP contains about 13\% industrial wastewater and $2 \%$ of hospital wastewater, while WWTPs in Mikołajki and Lidzbark contain municipal wastewater only from households. Wastewater samples (each with the volume of $2.0 \mathrm{~L}$ ) were collected into sterile bottles, transported to the laboratory at a temperature of $4^{\circ} \mathrm{C}$ and processed on the day of collection. 
Table 1. Technical description of wastewater treatment plants.

\begin{tabular}{|c|c|c|c|}
\hline Location & $\begin{array}{c}\text { Average } \\
\text { processing } \\
\text { capacity }\end{array}$ & Treatment system & Wastewater type \\
\hline Biskupiec & $1279 \mathrm{~m}^{3} / \mathrm{d}$ & mechanical-biological & $\begin{array}{c}\text { municipal } \\
\text { (industrial wastewater 13\%; } \\
\text { hospital wastewater: 2\%) }\end{array}$ \\
\hline Mikołajki & $1188 \mathrm{~m}^{3} / \mathrm{d}$ & $\begin{array}{c}\text { sequencing batch reactor } \\
\text { (SBR) }\end{array}$ & municipal \\
\hline Lidzbark & $582 \mathrm{~m}^{3} / \mathrm{d}$ & $\begin{array}{c}\text { mechanical-biological with } \\
\text { increased nutrient removal }\end{array}$ & municipal \\
\hline
\end{tabular}

\subsection{Genomic DNA extraction}

Wastewater samples $(1000 \mathrm{~mL}$ of untreated wastewater samples and $2000 \mathrm{~mL}$ of untreated wastewater samples) were passed through $0.2-\mu \mathrm{m}$ standard mixed cellulose filters with hydrophobic edge (Merck, Millipore). Then, the filters were transferred to a sterile screw cap tubes $(50 \mathrm{~mL})$, and stored at $-20^{\circ} \mathrm{C}$ for the further analysis. In the next step, $30 \mathrm{~mL}$ of $1 \mathrm{x}$ PBS was added to the tubes. They were shaken $(200 \mathrm{rpm}, 3 \mathrm{~h})$ at room temperature. After that, the entire precipitate was transferred to $2.0 \mathrm{~mL}$ Eppendorf tubes and centrifuged $(9000 \mathrm{rpm} / \mathrm{min}$, $15 \mathrm{~min})$. DNA was extracted using the two DNA isolation kits: i) Fast DNA SPIN Kit for Soil (MP Biomedicals) and ii) Genomic Micro AX Bacteria Gravity (A\&A Biotechnology), according to the manufacturer's instructions. The concentration and quality of extracted DNA was determined by Nanodrop spectrophotometer (NanoDrop ${ }^{\circledR}$ ND-1000, NanoDrop Technologies, Wilmington, DE). Genomic DNA was stored at $-20^{\circ} \mathrm{C}$ for further analysis.

The FastDNA ${ }^{\circledR}$ SPIN Kit for Soil uses modern technology of cells lysis based on homogenization of samples by multidirectional, simultaneous impaction with lysing matrix particles. Following lysis, samples are centrifuged to pellet soil, cell debris and lysing matrix. DNA is purified from the supernatant with a silica-based procedure using SPIN filters streamline silica handling. Eluted DNA is ready for PCR analysis.

The Genomic Micro AX Bacteria Gravity kit uses the gravitational flow method (Gravity flow). The technology developed by A\&A Biotechnology uses only the natural force of gravity and capillary phenomena. This kit based on traditional extraction methods using enzymatic digestion. Thanks to the specially developed ion-exchange membrane and the receiving tube, free flow of solutions and the elution of isolated DNA are possible. Functional description kits for DNA isolation are according to the manufacturer's instructions.

\subsection{Detection of specific markers of Bacteroides fragilis group, $B$. dorei and identification of resistance genes by standard PCR method}

The $b f r$ and HF183/BacR287 genes were determined by standard PCR in genomic DNA of all wastewater samples. Additionally, the occurrence of antibiotic-resistance genes for: betalactams $(\operatorname{cep} \mathrm{A}, c f x \mathrm{~A})$, tetracyclines $(\operatorname{tet}(\mathrm{Q}))$ and $\mathrm{MLS}$ mechanism $(\operatorname{erm} \mathrm{F}, \operatorname{lin} \mathrm{A})$ was determined. All analysed antibiotic-resistance genes are specific to Bacteroides fragilis group. Primers had been previously validated (for primer sequences, additional details regarding PCR conditions, references for each sequence, see Table 2). After PCR amplification, $5 \mu \mathrm{L}$ of each amplified fragment of DNA with $1 \mu \mathrm{L}$ of the loading buffer were separated by electrophoresis in 1.5\% agarose gel (Merck) stained with ethidium bromide $(0.5 \mu \mathrm{g} / \mathrm{mL})$. The products were electrophoresed for $10 \mathrm{~min}$ at $130 \mathrm{~V}$ and for $60 \mathrm{~min}$ at $90 \mathrm{~V}$ in $0.5 \times$ TBE buffer and visualized. 
Table 2. Oligonucleotide primers and parameters used for the detection of genes, with PCR analysis.

\begin{tabular}{|c|c|c|c|}
\hline Gene & Primers $5^{\prime}-3^{\prime}$ & PCR cycles & Reference \\
\hline$b f r$ & $\begin{array}{c}\text { CTGAACCAGCCAAGTAGCG } \\
\text { CCGCAAACTTTCACAACTGACTTA }\end{array}$ & $\begin{array}{l}94^{\circ} \mathrm{C} 20 \mathrm{~s}, 52^{\circ} \mathrm{C} 1 \\
\min , 72^{\circ} \mathrm{C} 30 \mathrm{~s}, 35 \mathrm{x}\end{array}$ & 4 \\
\hline $\begin{array}{c}\text { HF183 } \\
\text { BacR287 }\end{array}$ & $\begin{array}{c}\text { ATCATGAGTTCACATGTCCG } \\
\text { CTTCCTCTCAGAACCCCTATCC }\end{array}$ & $\begin{array}{l}95^{\circ} \mathrm{C} 5 \mathrm{~s}, 60^{\circ} \mathrm{C} 30 \\
\mathrm{~s}, 72^{\circ} \mathrm{C} 30 \mathrm{~s}, 40 \mathrm{x}\end{array}$ & 22,23 \\
\hline серA & $\begin{array}{l}\text { TTTCTGCTATGTCCTGCCT } \\
\text { ATCTTTCACGAAGACGGC }\end{array}$ & $\begin{array}{l}95^{\circ} \mathrm{C} 15 \mathrm{~s}, 56^{\circ} \mathrm{C} 30 \\
\mathrm{~s}, 72^{\circ} \mathrm{C} 1 \mathrm{~min}, 35 \mathrm{x}\end{array}$ & 24 \\
\hline$c f x A$ & $\begin{array}{l}\text { TGACTGGCCCTGAATAATCT } \\
\text { ACAAAAGATAGCGCAAATCC }\end{array}$ & $\begin{array}{c}95^{\circ} \mathrm{C} 15 \mathrm{~s}, 55^{\circ} \mathrm{C} 1 \\
\min , 72^{\circ} \mathrm{C} 30 \mathrm{~s} \\
35 \mathrm{x}\end{array}$ & 24 \\
\hline $\operatorname{tet}(Q)$ & $\begin{array}{l}\text { TTATACTTCCTCCGGCATCG } \\
\text { ATCGGTTCGAGAATGTCCAC }\end{array}$ & $\begin{array}{c}94^{\circ} \mathrm{C} 1 \min , 55^{\circ} \mathrm{C} \\
1 \min , 72^{\circ} \mathrm{C} 1.5 \\
\min , 35 \mathrm{x}\end{array}$ & 25 \\
\hline ermF & $\begin{array}{l}\text { TAGATATTGGGGCAGGCAAG } \\
\text { GGAAATTGCGGAACTGCAAA }\end{array}$ & $\begin{array}{c}95^{\circ} \mathrm{C} 15 \mathrm{~s}, 58^{\circ} \mathrm{C} 1 \\
\min , 72^{\circ} \mathrm{C} 30 \mathrm{~s} \\
35 \mathrm{x}\end{array}$ & 24 \\
\hline $\operatorname{lin} A$ & $\begin{array}{l}\text { CTGGGGAGTGGATGTCTTGT } \\
\text { AGTTGGCTTGTTTGGAAGTG }\end{array}$ & $\begin{array}{c}95^{\circ} \mathrm{C} 15 \mathrm{~s}, 60^{\circ} \mathrm{C} 30 \\
\mathrm{~s}, 72^{\circ} \mathrm{C} 30 \mathrm{~s}, 35 \mathrm{x}\end{array}$ & 24 \\
\hline
\end{tabular}

\section{Results}

The presence of the 16S rRNA gene specific to BFG (bfr), B. dorei (HF183/BacR287) and genes encoding resistance to beta-lactams (cep A, cfx A), MLS (lin $\mathrm{A}, \operatorname{erm} \mathrm{F})$ and tetracyclines $(\operatorname{tet}(\mathrm{Q}))$ in untreated and treated wastewater was determined in genomic DNA extracted with the use of two commercial kits, and the results are presented in Table 3. All of the analyzed antibiotic-resistance genes are specific to $\mathrm{BFG}$, including $B$. dorei.

\subsection{The presence of the 16S rRNA gene specific to $B$. fragilis group and B. dorei}

The presence of the 16S rRNA gene specific to BFG (bfr) and B. dorei (HF183/BacR287) was determined in all wastewater samples analyzed with both DNA extraction kits. These results could indicate that both untreated and treated wastewater from the analyzed WWTPs is contaminated with BFG and B. dorei.

\subsection{The occurance of genes encoding resistance to beta-lactams, MLS and tetracyclines}

The $c f x \mathrm{~A}$ gene encoding resistance to beta-lactams was identified in genetic material isolated from all samples of untreated wastewater with the use of FastDNA SPIN Kit for Soil. In the analyses performed with the use of the Genomic Micro AX Bacteria Gravity Kit, the $c f x \mathrm{~A}$ gene was detected only in untreated wastewater transported to the WWTPs in Biskupiec and Lidzbark. None of the analyzed wastewater samples harbored the cepA gene, regardless of the applied DNA extraction kit.

The compared DNA isolation kits differed in their ability to detect $\operatorname{lin} \mathrm{A}$ and $\operatorname{erm} \mathrm{F}$ genes encoding bacterial resistance to MLS. Genetic material isolated with the first DNA extraction kit (FastDNA SPIN Kit) from untreated wastewater conveyed to WWTPs in Biskupiec and Lidzbark and from treated wastewater discharged from the WWTP in Mikołajki harbored the $\operatorname{lin} \mathrm{A}$ gene. The ermF was not detected only in untreated wastewater transported to the WWTP 
in Mikołajki where genetic material was isolated using Genomic Micro AX Bacteria Gravity Kit. In analyses conducted with the use of the second DNA extraction kit (Genomic Micro AX Bacteria Gravity Kit), $\operatorname{lin} \mathrm{A}$ and $\operatorname{erm} \mathrm{F}$ genes were identified in all samples of genetic material in treated wastewater.

The $\operatorname{tet}(\mathrm{Q})$ gene encoding resistance to tetracyclines was detected in all DNA samples isolated from wastewater with the use of both DNA extraction kits.

Table 3. The presence of the 16S rRNA gene specific to BFG, $B$. dorei, and genes encoding resistance to beta-lactams, MLS and tetracyclines in samples of untreated and treated wastewater analyzed with two DNA extraction kits.

\begin{tabular}{|c|c|c|c|c|c|c|c|c|}
\hline \multirow{3}{*}{\multicolumn{2}{|c|}{ WWT }} & & & & & & & \\
\hline & & \multicolumn{7}{|c|}{ FastDNA SPIN Kit for Soil } \\
\hline & & $b f r$ & $\begin{array}{c}\text { HF183/ } \\
\text { BacR287 }\end{array}$ & $c f x \mathrm{~A}$ & cepA & $\operatorname{lin} \mathrm{A}$ & erm $\mathrm{F}$ & $\operatorname{tet}(\mathrm{Q})$ \\
\hline \multirow{2}{*}{ Biskupiec } & UWW & & & & & & & \\
\hline & TWW & & & & & & & \\
\hline \multirow{2}{*}{ Mikołajki } & UWW & & & & & & & \\
\hline & TWW & & & & & & & \\
\hline \multirow{2}{*}{ Lidzbark } & UWW & & & & & & & \\
\hline & TWW & & & & & & & \\
\hline & II) & \multicolumn{7}{|c|}{ Genomic Micro AX Bacteria Gravity } \\
\hline \multicolumn{2}{|l|}{ WWTP } & $b f r$ & $\begin{array}{c}\text { HF183/ } \\
\text { BacR287 }\end{array}$ & $c f x \mathrm{~A}$ & серA & $\operatorname{lin} \mathrm{A}$ & erm $\mathrm{F}$ & $\operatorname{tet}(\mathrm{Q})$ \\
\hline \multirow{2}{*}{ Biskupiec } & UWW & & & & & & & \\
\hline & TWW & & & & & & & \\
\hline \multirow{2}{*}{ Mikołajki } & UWW & & & & & & & \\
\hline & TWW & & & & & & & \\
\hline \multirow{2}{*}{ Lidzbark } & UWW & & & & & & & \\
\hline & TWW & & & & & & & \\
\hline
\end{tabular}

\section{Discussion}

The compared DNA isolation kits differed in their ability to detect ARGs in untreated and treated wastewater. The Genomic Micro AX Bacteria Gravity Kit failed to identify ARGs in five wastewater samples. These results indicate that the Genomic Micro AX Bacteria Gravity Kit was less effective than the FastDNA SPIN Kit for Soil Kit in isolating genomic DNA from wastewater samples. In consequence, selected analyses of drug-resistance genes produced false negative results. Differences in the quality of DNA isolated with various extraction kits have also been reported by other authors. Claassen et al. [18], Kennedy et al. [19], Tomaso et al. [21] and Demeke and Jenkins [26] demonstrated that analyses of genetic material isolated from the same sample produced different results when various DNA extraction kits were used.

The $b f r$ and HF183/BacR287 genes, the specific markers of BFG and B. dorei, are localized in the conserved region of the 16S rRNA gene [3,4]. The presence of these genetic markers in environmental samples could be indicative of contamination with BFG. Research 
is being conducted to determine the applicability of these genetic markers, in particular the HF183/BacR287 gene, in analyses of microbiological contamination of aquatic environments with human feces [23, 27, 28]. In the present study, bfr and HF183/BacR287 genes were detected in all samples of untreated and treated wastewater from the analyzed WWTPs. These findings suggest that BFG and B. dorei were not completely eliminated in any of the studied WWTPs which rely on the activated sludge process. Therefore, WWTPs could be potential sources of BFG transmission to the natural environment. Haugland et al. [3] and Ahmed et al. [27] also reported the presence of human-specific Bacteroides markers in samples of untreated and treated wastewater.

All of the analyzed antibiotic-resistance genes are specific to BFG. In these group of bacteria, resistance to beta-lactams is encoded by cep $\mathrm{A}$ and $c f x \mathrm{~A}$ genes. The cep $\mathrm{A}$ gene encodes the synthesis of beta-lactamase which hydrolyzes most cephalosporins and penicillins. This is the most important mechanism of resistance to beta-lactam in BFG. The cf $x \mathrm{~A}$ gene is responsible for resistance to cefotaxime [24], and it is frequently detected in clinical BFG strains resistant to beta-lactams [23, 29]. In this study, $c f x A$ was detected only in untreated wastewater, which could suggest that this gene is effectively eliminated during wastewater treatment. The $c f x \mathrm{~A}$ gene was not identified in any samples of treated wastewater discharged from the evaluated WWTPs.

Infections caused by BFG are often treated with clindamycin, a lincosamide group antibiotic. However, research indicates that the prevalence of BFG strains resistant to clindamycin is on the rise. This resistance is related to the occurrence of the macrolidelinkosamide-streptogramin (MLS) mechanism, encoded by erm $\mathrm{F}$ and $\operatorname{lin} \mathrm{A}$ genes [30, 31]. These genes are prevalent in clindamycin-resistant clinical strains of BFG [24]. The presence of the ermF gene is often correlated with the tetracycline-resistance gene tet(Q). In tetracycline-resistant BFG strains, the tet $(\mathrm{Q})$ gene induces resistance to tetracyclines in the bacterial ribosome [32]. In this study, the evaluated DNA extraction kits differed in their ability to detect $\operatorname{erm} \mathrm{F}, \operatorname{lin} \mathrm{A}$ and $\operatorname{tet}(\mathrm{Q})$ genes. The FastDNA SPIN Kit for Soil supported the identification of all genes encoding resistance to MLS and tetracyclines in samples of untreated and treated wastewater from three WWTPs.

To the best of the authors' knowledge, this is the first ever study to analyze the presence of ARGs specific to BFG in untreated and treated wastewater from WWTPs. The results of this study indicate that antibiotic-resistance genes are not completely eliminated during the wastewater treatment process.

\section{Conslusions}

The results of this study support the formulation of the following conclusions:

- Commercial DNA extraction kits differ in their ability to detect antibiotic-resistance genes during standard PCR analyses.

- The DNA FastDNA SPIN Kit for Soil was more effective than the Genomic Micro AX Bacteria Gravity Kit in detecting drug-resistance genes in the isolated genetic material. The Genomic Micro AX Bacteria Gravity Kit failed to detect the full spectrum of drugresistance genes in Bacteroides spp.

- In the analyzed WWTPs, the $16 \mathrm{~S}$ rRNA gene specific to BFG and B. dorei, and linA, $\operatorname{erm} \mathrm{F}$ and $\operatorname{tet}(\mathrm{Q})$ genes were not completely eliminated from wastewater in the activated sludge process. Activated sludge treatment effectively removed the $c f x$ A gene encoding resistance to beta-lactams from wastewater.

This study was supported by grant no. UMO-2016/23/N/NZ9/02167 and no. UMO2016/23/B/NZ9/03669 from the National Science Center (Poland). 


\section{References}

1. M. Gajdacs, G. Spengler, and E. Urban, Antibiotics-Basel 6, 4 (2017)

2. H. M. Wexler, Clin. Microbiol. Rev. 20, 4 (2007)

3. R. A. Haugland, M. Varma, M. Sivaganesan, C. Kelty, L. Peed, and O. C. Shanks, Syst. Appl. Microbiol. 33, 6 (2010)

4. C. X. Liu, Y. L. Song, M. McTeague, A. W. Vu, H. Wexler, and S. M. Finegold, Fems Microbiol. Lett. 222, 1 (2003)

5. K. Kummerer, Chemosphere 75, 4 (2009)

6. E. Marti, J. Jofre, and J. L. Balcazar, Plos One 8, 10 (2013)

7. J. Xu, Y. Xu, H. M. Wang, C. S. Guo, H. Y. Qiu, Y. He, Y. Zhang, X. C. Li, and W. Meng, Chemosphere 119 (2015)

8. A. Osinska, E. Korzeniewska, M. Harnisz, and S. Niestepski, Sci. Total Environ. 577 (2017)

9. E. Korzeniewska, and M. Harnisz, J. Environ. Manage. 123 (2013)

10. E. Korzeniewska, A. Korzeniewska, and M. Harnisz, Ecotox. Environ. Safe. 91 (2013)

11. X. X. Zhang, T. Zhang, M. Zhang, H. H. P. Fang, and S. P. Cheng, Appl. Microbiol. Biot. 82, 6 (2009b)

12. L. Rizzo, C. Manaia, C. Merlin, T. Schwartz, C. Dagot, M. C. Ploy, I. Michael, and D. Fatta-Kassinos, Sci. Total Environ. 447 (2013)

13. J. Davies, G. B. Spiegelman, and G. Yim, Curr. Opin. Microbiol. 9, 5 (2006)

14. M. Harnisz, Environ. Pollut. 174 (2013)

15. M. Harnisz, E. Korzeniewska, S. Ciesielski, and I. Golas, Sci. Total Environ. 505 (2015)

16. X. X. Zhang, T. Zhang, and H. Fang, Appl. Microbiol. Biot. 82, 3 (2009a)

17. F. F. Reinthaler, J. Posch, G. Feierl, G. Wust, D. Haas, G. Ruckenbauer, F. Mascher, and E. Marth, Water Res. 37, 8 (2003)

18. S. Claassen, E. du Toit, M. Kaba, C. Moodley, H. J. Zar, and M. P. Nicol, J Microbiol. Meth. 94, 2 (2013)

19. N. A. Kennedy, A. W. Walker, S. H. Berry, S. H. Duncan, F. M. Farquarson, P. Louis, J. M. Thomson, J. Satsangi, H. J. Flint, J. Parkhill, C. W. Lees, G. L. Hold, and Uk Ibd Genetics Consortium, Plos One 9, 2 (2014)

20. N. Mahmoudi, G. F. Slater, and R. R. Fulthorpe, Can. J. Microbiol. 57, 8 (2011)

21. H. Tomaso, M. Kattar, M. Eickhoff, U. Wernery, S. Al Dahouk, E. Straube, H. Neubauer, and H. C. Scholz, Bmc Infect. Dis. 10 (2010)

22. E. Bernhard, and K. G. Field, Appl. Environ. Microb. 66, 4 (2000)

23. H. C. Green, R. A. Haugland, M. Varma, H. T. Millen, M. A. Borchardt, K. G. Field, W. A. Walters, R. Knight, M. Sivaganesan, C. A. Kelty, and O. C. Shanks, Appl. Environ. Microb. 80, 10 (2014)

24. Z. Eitel, J. Soki, E. Urban, E. Nagy, and Escmid Study Grp Anaerobic, Anaerobe 21 (2013)

25. L. K. Ng, I. Martin, M. Alfa, and M. Mulvey, Mol. Cell. Probe. 15, 4 (2001)

26. T. Demeke, and G. R. Jenkins, Anal. Bioanal. Chem. 396, 6 (2010)

27. W. Ahmed, B. Hughes, and V. J. Harwood, Water 8, 6 (2016)

28. Y. P. Cao, M. Sivaganesan, C. A. Kelty, D. Wang, A. B. Boehm, J. F. Griffith, S. B. Weisberg, and O. C. Shanks, Water Res. 128 (2018)

29. A. Sarkar, G. P. Pazhani, R. Dharanidharan, A. Ghosh, and T. Ramamurthy, Anaerobe 33 (2015)

30. Y. Nakajima, J. Infect. Chemother. 5 (1999)

31. J. Wang, N. B. Shoemaker, G. R. Wang, and A. A. Salyers, J. Bacteriol. 182, 12 (2000)

32. E. Szekely, Z. Eitel, S. Molnar, I. E. Szasz, D. Bilca, and J. Soki, Anaerobe 31 (2015) 